\title{
Eのつくり 今ి
}

\section{I. 原 料 米}

より曾かな，よりエレガントな生活をモットーに，啫好品に対する消 費者の風当りが強くなってきた。清酒では製造法の表示まで迫まられよ うとしている。清酒のあるへき姿は一体何であるのか。単に昔の造りに 戻ることではないはずである。現代に受け継がれている技術の中には, あるいは暗中模索時代のナンセンス的なものがあったり, やはり合理的 な貫重なものがあったりするであろう。酒造工程おのおのについて，斯 界の諸権威による技術变退の追跡をお願いした所以である。

今回は酒造米に対する価値基準が，酒造技術の進歩と共にどのように 変化してきたかを, 広籁な文献調查により系統だてて解説していただい た。

\section{国税庁醇造試験所}

野白喜 久雄

米は清酒の最も重要な原料であり, 米と製成酒の品質 との関係は昔から全酒造人の関心のまととなっていた。 しかし米に対する考方方は，その当時の知識水準，技術 水準あるいは経済状況によって年々変化して扣り, 今後 も同様の経過を辿るものと思われる。

米について先人はどのように考党，またその考方方が 時代の経過とともにどのよらに変っていったか, しばら く跡を追ってみよう。

\section{1. 酒造原料米の選定基準の变遷 一一明治末期まで—}

清酒䤑造法にはじめて科学のメスを入れたアトキンソ ン (英人, 東京大学理科大学挔雇教師) は, 明治 14 年, その著書「日本醮酒編」の中で酒造原料米について触れ 次のよらに述べている。

「酒造原料として最良の米は美濃, 肥後, 伊勢, 尾張, 遠江, 肥前から来る。次浪い米は, 房州, 丹波, 但馬 で, 3 番目の米は, 上総, 下総, 武蔵, 加賀の 産であ る。括かぼは粕が少ないので酒造用に適するといわれて いるが，自分は確かめたことはない。」

この格付けがどのような基準によってなされたものか は全く不明であるが，「括かぼは粕が少なくて酒造用に 適する」とある所から考えれば「溶け易さ」すすなわち後 の軟質といら性質が一つの基準になっていたことが想像
される。また明治以前の米の銘柄は国または所領単位の 地域銘柄であって，その中に今日いら所の品位(等級), 品種, 包装, 量目, 保管, 輸送期間その他種々の要素が 包含された総括評価であったことからすれば，上位に格 付けされた産地の米が品位（調製の良否）等の点ですぐ れていたことも考えられる。

何れにしても明治未期までは確固とした選定基準はな かったと思われ，筆者の調べた限りでは扮拉よそ次のよ らな状況であった（何れる当時の酒造技術書から抜粋し たものである)。

明治 18 年：「米は近隣の良質米を使らのよがい。その 中でる特に大粒米, 容積重の大きい米を選ぶこと。普通 米の容重は 1 升当り 360 378 多であるが, 370 外以上 の米が良い。」(小野藤介, 清酒醇造法実験説) 370 多は 約 $1380 \mathrm{~g}$ であり現在の標準からすればかなり小さい米 である。

明治 22 年:「酒造米には飯にして一番うまい甘味の 強い粘りのある米が良い。上方では摂津, 播州, 明石, 高砂の米を使う。しかしこれでなくとも上質の米ならど この米でもよい。粒がよく揃っていることが大切であ る。」(徳野嘉七, 日本酒実業改良問答)

明治 22 年:「良酒を得るには米よりも醸造法の研究 が大切である。」(実行改良清酒醸造法)

明治 27 年:「酒造米としては次のものがょい。(1) 
米粒が堅硬で量目重く, 腹の白味少なく, 味は甚だしく 美味でないもの，(2) 大粒で筋の浅いもの，(3) 乾燥適 度のもの，(4) 調製良好のもの，(5) 光沢良好のもの。 なお，らまい米は蛋白，糖分，糊精に富み，蒸し米に粘 り気多く製赖が困難である。」(関五郎松, 醇海拾玉, 酒 造のともしび）うまい米，すなわち粘り気のある米が不 可であると説いてあるのは注目に值する。大粒, 調製, 乾燥, 光沢, 筋等についても触れていてこの基準は現代 飞も通用するるのが多い。

明治 38 年:「酾造用米の性質は醇造用水の性質程で はないがそれでも䤑造の成績に大きな影響を及ぼすか ら，その選定には注意を払わねばならない。しかし水の 場合のごとく必ずしも専門家の鑑定を受ける必要はな い。次の標準によれば大過ないであろう。（1）有害菌に 侵されていないるの，(2) 普通蒸してよく糊化するる の, (3) 蒸米として余り粘らないもの。最良の米がいか なるものであるかは答が難かしい。米の性質は千差万別 であるから, 現在の研究程度では明確に言い表わすこと ができない。」(中村政五郎, 関東各地の講習会での講演) 後に各地の鑑定部長を歴任し酒造技術界の重鎮とうたわ れた中村政五郎氏の説であるが，この当時は米よりもむ しろ水重きを招いていたことがらかがわれる。

明治 43 年:「どの米が酒造に適しているかまだはっ きりしていない。酒造家の多くは近隣の上質米を選んで 使用する。灘は摂播二国の米を使用する。らまい米が不 可といらのは仮説に過ぎない。灘地方の原料米は食用と しても良好である。米質の硬いものは製樬の際八ゼ込み が悪くヌリ八ゼとなるから，䊝造りには軟かい米が適し ている。」(今北治三郎，灘酒醇造操技）著者は杜氏とし て永年現場で直接酒造りに従事していた人で, その後各 地を指導して回ったこともあるらしい。

近隣の良質米を使用せよというのは当時の交通輸送状 沉を考学れば当然のことであろら。海運か牛馬に頼る他 輸送の便のなかった時代では, いくら良質米であっても 遠方から運んでくることは到底出来ない相談であった。

\section{2. 軟留之硬留}

同じ頃当時醸造試験所飞勤務していた鹿又親氏はこれ までの酒造原料米に対する知識を集大成し, 明治 43 年 7 月 14 日, 第 2 回栃木県清酒品評会䘫賞授与式におい て次の通り述べている。

「酒造の原料は米と水と稞の三者である。水と種婅に ついては研究が充分に行届いているが，原料米に関して は学術的にもまた実地的にも秩序ある研究が甚だ乏しい ように思う。私の寡聞かも知れないが, 日本酒の䁔造法 を記載した雑誌や書籍を見てる，また実際家に聞いて
も，まだ，かくのごとき米は酒造上最も良好なりといら 学説を聞かない。

今日一般に酒造米の選定標準として記載してあるのを 見ると，酒造米の適否鑑定といらょりむしろ普通の産米 検査の判定審查標準といら方が適当している。もちろん 酒造米としても米として具借すべき条件は同じである が，全部が一致しなければならないものではない。

元来酒造米, 語をかえていえば蒸米として必要な条件 は次の通りである。

1）蒸慨が容易で均等であること。

2）蒸米となってから整のはぜこみがよいこと。

3）蒸慨により糊化した測粉が容易に且つ充分に糖化 作用を受けること。

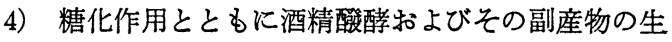
産を好適に営むに充分であること。

5）フーゼル油のごとき物質の生因となる成分を含有 しないこと。

6）製成酒に異臭味を与える成分を含有しないこと。

7）有害菌の発育に適しないこと。

もっとも前に申した通り具体的の実験をしたわけでは なく，主産地の酒造米の性質から帰納したるのであるか ら，その積りで聞いていただきたい。

1）のためには，粒に不同なく乾燥充分, 色沢良好で 夾雅物を混しないことを必要とし，2） 7)のためには， 揤粉質に富み剛性が余り大でなく, 比重軽く水分, 窒素 分, 灰分が比較的少なく風味淡白であることを要する。 これは腹白米*によって達成されるのである。要するに， 灘, 広島地方のように, 最も醇美な酒を生産する地方の 酒造米が一般酒造米として適当である。な拉，原料がい かによくても，操作との他に欠点があれば，もとより醇 良酒は出来ないことを申し添えておく。」

酒造米の良否の判定を蒸米の時点で行ならべきことを 説いたのはすぐれた見解である。

少し括くれて江田鎌治郎氏も明治 45 年との大著の中 で次のよらに述べている。

「優良な酒造米とされているすのは摄津米, 播州米, 備前米等で, 何れも軟質米に属している。酒造米として どのようなものを良好とするかは今な技学術的に説明で きないが，その軟質を可とすることだけは確かである。 硬質米を不可とする理由は次の通りである。

1）蒸飷が困難である。

2）釉のはぜこみが不良である。

3）蒸米の溶解糖化が不良である。

4) 酒母が早涌きする。

5）醪の酸醉が不充分である」。 
鹿又, 江田両氏之も，蒸し，䊝の八ゼ込み，溶解糖化 に重点を拈いているが、この性質がいわゆる軟質と称さ れるものである。米の硬軟には精白度（精米歩合）の問 題がからむのであるが，これについては後に述べること にしてここでは触れない。

さて軟質, 硬質についてはさらに詳しい解説が大正 3 年に䤑造試験所から発表されているので, 次に要点を記 してみよう。

「軟質の米は経験によれば大粒心白である。硬質米は 蒸しが困難で蒸し後の硬化が甚だしく，ために椈のハゼ 达み不良となり糖化力む小さい。米粒の溶解は不良で酒 母は早湧きとなり，もろみは粕量多く味の薄い酒とな る。また酒の貯蔵性も悪い。硬質米を使用する場合は精 白を十分にするとともに米洗いも十分にして糠を完全に とりまた漫漬を長くしなければならない。」

この頃になれば米の硬軟が最る重要な性質であること に評価が定まり，従って判定基準もおのずから一致して きたようである。その頃のようにくろい米であれば当然 糖化も悪い筈であり，枆も米粒の外側にのみ菌系の回っ たいわゆるヌリハゼ整では糖化力が低くなるし，むろみ の酸酵も強烈であろらからこれらの原因が重なって薄辛 い酒になるのは理の当然である。これを防ぐために溶け 易い米, 軟質米が要求されたのであり, 大粒心白米が軟 質であることを発見したのは酒造業者にとって大きな幸 運であったと言わねばならない。一般的に言って大粒心 白米の被糖化性, 消化性が大であることは最近の研究で も確認されている。

軟質米が大粒心白であることは上にも述べられている が，全国の酒造原料米の性質を調查して酒造に適する原 料米が大粒心白であることを確かめ, 好適米といら概念 を確立したのは醸造試験所の佐藤寿衛氏であった。大正 中期から後期にかけての一連の研究がそれで，これ以後 「好適米」といら言葉が普及する一方, 酒造技術書中の原 料米に関する記述はすべて類似したもの，すなわち大粒 心白軟質を良しとすることになってしまったのである。

\section{3. 現在の選定基準}

酒造原料米選択の基準に関する問題は軟質米，つまり 蒸米が軟かく，枆菌が八ゼ込み易く，かつ溶解糖化の良 好な米を良しとすることに決まり，また大粒心白米がこ れらの性質を備えていることが明らかにされて一芯落着 した。大正後期から昭和戦前むではこの基準がほとんど 何の疑いもなく受け入れられてきたと考兄られる。

しかし「米と醸造法との間には深い関係があるので, 醇造法さえ適当に選択すれば米質にこだわる必要はな く，逆に大粒軟質米でも操作を誤れば失敗する」と説い
た人もいた（大正 6 年，山本敬三）。ただし原料米に関 する学術的研究がまだ十分でないので, 米質に適応した 処理方法, 醸造技術の選択が非常に困難であると述べて いる。

また昭和 9 年, 小森威吉氏は備前米尊重に反論して, 「なる程備前米は軟質であるが, その性質が好適であった のは大正 7 8 年頃の精白度が 2 割 5 分〜3 割であった 時代のことであり, 現在のように 5 割る精白するように なっては軟か過ぎて使い難いのが実情である。精白度を 高めるとどの原料米も性質が似てくるから, 必ずしも備 前米を必要とはしない。」と述べている(酒造界の錯覚)。 次回に述べるように, 大正時代の 2 割 5 分は横型精米 機による精白度であり, 昭和 9 年の 5 割は堅型精米機に よるものであろらから，この両精白度の差異はさらに扗 大するわけであるが，何れにしても原料米の選定を精白 度との関連で考虑したのは非常な卓見と言わねばならな w。

さて，現在の選定基準はどのようなものであろらか。 これについては本誌の昨年 10 月号に「酒造原料米の考 え方」として試論を発表したので詳細はとれを御参照め りたい。結論だけを言えば, 精米方法の改良, 精米歩合 の低下（精白度の向上）により現在の原料白米は大抵軟 質になっている。したがって軟質を目的として高価な醸 造用玄米（好適米）を購入するのはムダである。好適米 の購入は, 同一産地, 同一品種の原料米の使用により每 年の酒造工程を安定させることを目的としたものであ る。一般米を使用しても技術水準の高い庫ではこの安定 が得られるわけで，そこに技術の役割があると考觉る。 この最後の所論は大正 6 年の山本敬三氏の意見と同じで あるが，その当時不可能であったことも今や可能になっ たものと筆者は信じて疑わないものである。

るら一つ, 選定基準として見逃し得ないのは「価格」 である。これは好適米と一般米との場合にも当てはまる のであるが, 同じ一般米でも品種, 産地, 等級によって かなり価格差がある。ただしこの基準を活用するには安 価な米を使って高価な米で造ったのと同じ品質の清酒を 造る技術を開発する必要があろう。安価な米の中には下 位等級米，水分過多米，古米等があるが，精米歩合の高 い白米も結局は安価な米につながるもので, 後者は特に 省資源の上からも重要である。

\section{4. 酒造原料米の品種}

酒造原料米としてどのような品種が使用されていたか については，好適米のみ限っても甚だ文献が乏しい。 好適米以外の一般米については活とんど皆無と称しても 過言ではない。一般米の俵にも品種名がつくようになっ 
第 1 表 水稲の品種別作付状況の推移

\begin{tabular}{|c|c|c|c|c|c|c|c|c|c|c|c|c|c|c|c|c|}
\hline & \multirow{2}{*}{ 位 } & \multicolumn{3}{|c|}{1908 (明 41) } & \multicolumn{3}{|c|}{1925 (大 14) } & \multicolumn{2}{|c|}{1937 (昭 12) } & \multicolumn{3}{|c|}{1943 (昭 18) } & \multicolumn{2}{|c|}{1958 (昭 33) } & \multicolumn{2}{|c|}{1973 (昭 48) } \\
\hline & & 品 & 種 & $\%$ & 品 & 種 & $\%$ & 種 & $\%$ & 品 & & $\%$ & 品 種 & $\%$ & 品 種 & $\%$ \\
\hline 1 & & 神 & 力 & 21.8 & 神 & 力 & 13.8 & 旭 & 19.7 & 旭 & & 13.9 & 金 南 風 & 4.5 & 日 本 晴 & 12.2 \\
\hline 2 & & 爱 & 国 & 5.1 & 愛 & 国 & 6.8 & 陸 羽 132 号 & 8.2 & 陸羽 132 & 号 & 6.3 & 费林 18 号 & 3.7 & ニシヒカリ & 8.2 \\
\hline 3 & & 雄 & 町 & 5.1 & s & 尾 & 5.3 & 爱国 & 7.3 & & 国 & 4.5 & 農 林 22 号 & 3.1 & ササニシキ & 6.3 \\
\hline 4 & & 関 & 取 & 2.8 & 坊 & 主 & 2.5 & 主 & 6.1 & 農 林 1 & 号 & 4.2 & ササシグレ & 2.8 & レイホウ & 6.3 \\
\hline 5 & & 竹 & 成 & 2.7 & 雄 & 町 & 2.1 & 坊主 & 5.0 & 㻃 林 6 & 号 & 3.4 & 農 林 29 号 & 2.5 & ト $\Xi ニ シ キ$ & 6.0 \\
\hline 6 & & 白 & 玉 & 2.3 & 豊 & 国 & 2.0 & 農 林 1 号 & 4.2 & 銀 坊 & 主 & 3.2 & 蕽 林 17 号 & 2.4 & ホウネンワセ & 5.8 \\
\hline 7 & & 大 & 場 & 2.1 & 旭 & & 1.5 & 三 井 & 2.6 & 農 林 8 & 号 & 2.8 & 藤 坂 5 号 & 2.3 & 越 路早生 & 2.8 \\
\hline 8 & & 石 & 白 & 1.8 & 関 & 取 & 1.1 & 福 坊 主 & 2.5 & 福 坊 & 主 & 2.2 & 農 林 41 号 & 2.0 & トドロキワセ & 2.7 \\
\hline 9 & & 都 & & 1.6 & 急 & 治 & 1.0 & 神 & 2.1 & 楚 知 & 旭 & 1.9 & ギンマサリ & 1.9 & $v 1 \times 1$ & 2.5 \\
\hline 10 & & 白 & 笹 & 1.1 & 改良爱 & 国 & 0.8 & 撰 一 & 1.4 & 千 本 & 旭 & 1.8 & ミホニシキ & 1.7 & キョニシキ & 2.2 \\
\hline 11 & & 名古 屋 & 白 & 1.0 & 賏 良 & 都 & 0.7 & 千 本 旭 & 1.4 & 宝(道海神) & 力) & 1. 8 & ハッニシキ & 1.5 & 中生新千本 & 1.9 \\
\hline 12 & & 須賀一 & 本 & 0.9 & 坊 & 主 & 0.7 & 神山 & 1.3 & 農 林 20 & 号 & 1.7 & 越 路早生 & 1.5 & フジミノリ & 1.4 \\
\hline 13 & & 豊 & 後 & 0.9 & 撰 & 二 & 0.7 & 宝(道海神力) & 1.2 & & 井 & 1.4 & 農 林 25 号 & 1.5 & $ヤ \nabla ヒ ゙=$ & 1.2 \\
\hline 14 & & 細 & 秙 & 0.8 & 無芒愛 & 国 & 0.7 & 治 & 1.0 & 農 林 12 & 号 & 1.3 & チョウカイ & 1.4 & 秋 晴 & 1.2 \\
\hline 15 & & 早 & 屋 & 0.8 & 弁 & 虔 & 0.5 & 弁典 & 0.8 & 林 18 & 号 & 1.3 & ホウネンワセ & 1.1 & ヤマホウシ & 1.1 \\
\hline 16 & & 万 & 作 & 0.7 & 相 & 徳 & 0.4 & 幾 内早生 & 0.8 & 瑞 & 艟 & 1.1 & ト ワ & 1.1 & ササミノリ & 1.1 \\
\hline 17 & & 白 & 稲 & 0.7 & 八 & 反 & 0.4 & 不作 不知 & 0.8 & 農 林 17 & 号 & 1.1 & コガネニシキ & 1.0 & アケボノ & 1.1 \\
\hline 18 & & 莗 & 尾 & 0.7 & 陸 羽 132 & 号 & 0.3 & 瑞曹 & 0.7 & 㕮 林 16 & 量 & 1.0 & 東山 38 号 & 0.9 & ゆ5なみ & 1.0 \\
\hline 19 & & 荒 & 木 & 0.7 & 日之出 & 選 & 0.3 & 開取 & 0.7 & 神 & 山 & 1.0 & アケボノ & 0.9 & $\neq \quad$ & 1.0 \\
\hline 20 & & 信 & 州 & 0.7 & 神 力 & 糯 & 0.3 & 神 徳 (神愛) & 0.7 & 富 & 国 & 0.9 & ベニセンニ゙ク & 0.9 & ほうりゆう & 1.0 \\
\hline \multicolumn{5}{|c|}{$\begin{array}{l}\text { 水稲作付面皘 (千 ha) } \\
\text { (農林省統計) } \\
2,815\end{array}$} & \multicolumn{3}{|c|}{2,993} & \multicolumn{2}{|l|}{3,044} & \multicolumn{3}{|c|}{2,967} & \multicolumn{2}{|l|}{3,079} & \multicolumn{2}{|l|}{2,570} \\
\hline
\end{tabular}

たのは, 昭和 44 年自主流通米制度発足の際, 米の銘柄 設定が行なわれて以来のことであり，それまでは産地名 は分っていても品種名は不詳のことが多かった。つまり 一般米は品種などはどうですよいとしか思われていなか ったのであろう。好適米の格差の増大, 生産量の漸隇等 を考学れば，今後は一般米の醸造適性についてももっと 注目すべきであり, 現在の研究もその方向に進められて いるのは御承知の通りである。

とああれ，どのような好適米，一般米が使用されてい たのであろらか。乏しい文献から探ってみることにす る。

好適米以外では前記「酒造米に対する考方方」にも記 してあるように，やはり多く作られていた品種が酒造に る多く使用されていたるのと思われる。ではどの品種が 多く作られていたのであろらか。明治 41 年からほぼ 15 年ごとの水稲作付状況は第 1 表のと伺りである。

この表をみて意外に思うのは大正年間までは大粒心白 種の雄町, 亀の尾, 穀良都がかなり大量飞生産されてい たことである。前記山本敬三氏の論説中にも「酒造米と して好適の心白米は関西地方では飯米とし好評である が，関東地方では心白の多い米を嫌う。」とあり，心白米 が大量に出回っていたことを裏付けている。な报原料米 の選定基準の所で述べたが，食用適米と酒造適米とがあ る人では相反し，ある人では合致したのは，この食習慣 の差異によるものとも考えられる。

雄町は慶応 2 年 (1866 年, 一説に上れば安政 6 年, 1859 年) 岡山県上道郡高島村大字雄町の岸本甚造氏の
育成した品種で, 戦前品評会華やかなりし頃は岡山雄 町, 特に赤磐郡産の雄町が最高品質の米と尊ばれたもの であった。現在も格差は最高であるが生産量は僅少であ る(47 年度 100 俵, 48 年度 91 俵, 49 年度 16 俵)。 亀の尾は大正時代東北地方で普及していたが，いもち病 に弱く耐肥性がないため, 昭和に入って陸羽 132 号に直 きかえられた。

酒造原料米の品種名がはじめて文献に表われたのは醸 造試験所による酒造法調查の際で, 明治 40 年福岡県城 島で大和, 神力, 明治 41 年伏見で山田穂, 天神穂, 明 治 42 年広島県竹原で神力, 雄町, 八反が使用されてい る。明治 40 年灘の庫の調查の時は品種名はなく, 久米 米, 東条米, 押部米 (以上播州米) 道祖本米, 東五百住 米 (以上搷津米) 々産地名を冠した米（いわゆる村米） であったが, 品種は山田穂, 天神穂, 野条穂等であった すのと思われる。なお戦前は播州米より摄津米の方がよ り軟質で評価も高かったという。

大正 5 年から 8 年にかけて佐藤寿衛氏の調查した酒造 米品種のらち主なるのは次の通りである。神力, 雄町, 山田穂, 天神穂, 石白, 亀の尾, 坊主, 愛国, 栄吾, 伊 勢錦, 勘力, 粟田等。西日本の米を主としたためか, 点 数では神力がズバ抜けて多く, その他雄町, 亀の尾す少 なくない。このらちのいくつかは第 1 表に出ている品種 で, 多く造られている品種が多く使われていることの証 拠となろう。

昭和 7 年から昭和 12 年まで連続 6 年間, 䁔造試験所 で全国酒造原料米基本調査を行なっている。この時集め 
た米は必ずしも優良米, 使用量の多い米とは限られてい ないが, 当時の原料米品種の一端をうかがうに足るもの といえよう。その品種は次の通りである（同一品種で年 度, 産地を異にするすのは一つにまとめた)。

愛国, 亀の尾, 伊勢錦, 陸羽 132 号, 山田穂, 雄町, 神力, 天神穂, 八反, 款良都, 坊主, 京の華, 千金丹, 日の出, 旭一号, 芸備錦, 満洲撫順米, 坊主 5 号, 坊主 6 号, 奥系 200 号, 穀良都, 大和日の出, 新山田穂, 野 条穂, 旭, 忠北錦 (朝鮮), 福坊主 (朝鮮), 大場, 酒の華, 北陸 12 号, 台北 6 号 (台湾), 三重錦, 太白, 強力, 関取, 弁慶, 豊国, 伊那穂一号, 秋田酒系 4 号, 農林 1 号, 前沢, 渡舟 6 号, 銀坊主, 一貴山大粒。

この中にも第 1 表の品種がいくつか見られる。内地米 ばかりでなく外地産米が使用されていたことす分って興 味深い。な拉山田錦は昭和 12 年に栽培されはじめたた め,この調査には顔を出していない。

戦後にる山村, 布川, 山田各氏らが好適米, 一般米を 分析している。その主なるのは次の通りである。

昭和 27 年度 (山村史郎) 八反, 山田錦, 雄町, 都祝, 旭 4 号, 東山, 穀良都, 千本, 農林 1 号, 白菊。

昭和 29 年度 (布川弥太郎) 信交 190 号, 日の出桜, 菊水, 雄亀, 亀町, 白菊, 白露, 旭号, 竹田早稲, 高根 錦。

昭和 38 年度 (山田正一) 改良信交, ササニシキ, サ サシグレ, フジミノリ, ハシニシキ, 中仙錦, 陸奥光,
高嶺錦, コシヒカリ, 銀若, クサブエ, 銀河 1 号, 山 吹, 南風新千本, 秀峰, ホウネンワセ, 越路早生, 五百 万石, 千秋楽, 越栄, キョスミ, 患林 29 号, 関東 54 号, 竹田早生, 白露, ヤエホ, 北陸 12 号, 京の華, 山田錦, 野条穂, 近畿 33 号, ミホニシキ, 伊吹, マンリョウ, 八反 10 号, 農林 22 号, 農林 44 号, 改良雄町, 兵庫 雄町, 朝日, ホウヨク, 改良八反流, 千代光, 十石, 東 山 38 号, 金南風, 農林 29 号, 農林 18 号。

戦前から酒米は特別の価格で取引されていたが, 戦後 は食糧管理法上の規定として酒米(醸造用玄米，好適米） に対する格差金がつくことになり, 昭和 25 年産米から 実施された。この時の指定品種は雄町（同等のるのを含 む), 穀良都, 野条穂, 白菊, 伊勢錦, 菊水, 竹田早生, 八反, 渡舟, 天神穂の品種であって, 山田錦は雄町之同 等のものとされた。

格差金制度はその後次々に改正されて品種が増加し， また産地を細分して差をつける措置がとられた。また昭 和 28 年度からは小粒品種にも格差金がつくことになっ た。小粒品種としてはまず朝日が取上げられたが，その 後農林 $27,23,22$ 号, ミホニシキ, 近畿 33 号等も指 定を受けた。しかし昭和 44 年, 自主流通米制度の発足 とともに小粒種はすべて醸造用玄米から外され，現在は 大粒種のみが銘柄指定を受けている。その数は昭和 49 年度で 22 品種, 32 府県, 65 産地品種である。

(つつく 